\title{
RISK FACTORS OF LEFT VENTRICULAR HYPERTROPHY IN MALE STUDENTS, IN MANADO, NORTH SULAWESI
}

\author{
Ribka L Wowor, GD Kandou, JML Umboh
}

Faculty of Public Health, Sam Ratulangi University, Manado, Indonesia

\begin{abstract}
Background: Left Ventricular Hypertrophy (LVH) is an independent risk factor of heart failure. Previous study reported several cases of LVH in college's students, so it's very important to know the risk factors of LVH in young adults. The aim of this study was to determine the risk factors of LVH in the male students at the Faculty of Medicine, Sam Ratulangi University.

Subjects and Method: This was an analytic observational study with casecontrol design. The study was conducted in Cardiology Section Prof. Dr. RD Kandou Manado Hospital, from November 2014 to January 2015. A sample of obese male students were selected for this study. The independent variables were central obesity, hypertension, hyperuricemia, smoking, lack of physical activity. The dependent variable was LVH. Odds Ratio and chi square test were used to determine the relationship between hypertension, smoking, central obesity, lack of physical activity, hyperuricemia, and LVH.

Results: Central obesity $(\mathrm{OR}=11.00 ; \mathrm{p}<0.001)$, hypertension $(\mathrm{OR}=7.37$; $\mathrm{p}<0.001)$, hyperuricemia $(\mathrm{OR}=3.27 ; \mathrm{p}=0.031)$, and lack of physical activity $(\mathrm{OR}=6.33 ; \mathrm{p}=0.025)$ were associated with $\mathrm{LVH}$.

Conclusion: Central obesity, hypertension, hyperuricemia, and lack of physical activity are associated with LVH in male obese students.
\end{abstract}

Keywords: Left Ventricular Hypertrophy, hypertension, central obesity, hyperuricemia, physical activity

Correspondence: Ribka L Wowor. Faculty of Public Health, Sam Ratulangi University, Manado, Indonesia. Email: wantaniaerwinfrans@yahoo.com. 